ORIGINAL ARTILE

AFRICAN JOURNAL OF CLINICAL AND EXPERIMENT AL MICROBIOLOGY ISBN 1595-689X SEPTEMBER 2018 VOL19 No.4 AJCEM/1839

COPYRIGHT 2018 https://dx.doi.org/10.4314/ajcem.v19i4.7

AFR. J. CLN. EXPER. MICROBIO. 19 (4):291 -302

http://www.ajol.info/journals/ajcem

\title{
COMPARATIVE STUDY OF MICROBIAL, PROXIMATE AND HEAVY METAL COMPOSITIONS OF SOME GASTROPODS, BIVALVE AND CRUSTACEAN SEAFOOD
}

\author{
Oranusi ${ }^{*}$, S., Effiong, E. D. and Duru, N. U. \\ Department of Biological Sciences, Covenant University, Ota, Nigeria \\ *Corresponding author; Email: solomon.oranusi@covenantuniversity.edu.ng
}

\begin{abstract}
Background: Seafood are known to be nutritionally rich, however, water bodies from where these foods are harvested are often burdened with wastes from industries, household and run-offs. Thus seafood can harbor pathogenic microorganisms and heavy metals which can pose a serious health hazard to consumers. Materials and Methods: In this study, $5 \mathrm{~kg}$ each of Littorina littorea, Achatina fulica,Tympanotonos fuscatus, Dorsanum miran, Egeria radiate and Penaeus notialis were investigated for microbial, proximate and heavy metal qualities using standard microbiological and chemical methods of analysis. Results: The gastropod mollusks Tympanotonos fuscatus, Littorina littorea and Achatina fulica had significantly $(\mathrm{p} \leq 0.05)$ higher microbial loads compared to other samples. All the samples had significantly $(p \leq 0.05)$ higher coliform counts compared to standard specifications. The microbial isolates from the samples included species of Bacillus, Klebsiellae, Citrobacter, Providencia, Pseudomonas, Staphylococcus aureus, Escherichia coli and Aspergillus niger, Aspergillus flavus, yeasts, Alternaria, Absidia, Rhizopus, and Mucor. Antibiogram of the isolates revealed multiple resistances with $79.55 \%$ and $66.67 \%$ resistance to antibacterial and antifungal agents respectively. The seafood was rich in protein $(8.0 \pm 0.03$ to $46.0 \pm 0.03 \%)$ and fat $(0.6 \pm 0.01$ to $8.8 \pm 1.00 \%)$ but low in carbohydrate $(1.18 \pm 0.84$ to $3.81 \pm 0.86 \%$ ). The heavy metal compositions of the seafood were generally low except for manganese $6.36 \pm 0.03 \mathrm{ppm}$ in Dorsanum miran and nickel $0.81 \pm 0.50 \mathrm{ppm}$ in Penaeus notialis. Conclusion: The microbial loads of the seafood are significantly $(\mathrm{p} \leq 0.05)$ higher in gastropods and more than acceptable standard, effective protection of water bodies for food cultivation and constant monitoring of seafood is necessary. Adequate processing and employing good manufacturing practices can reduce the microbial loads to an acceptable level and prevent food borne hazards that could be associated with seafood consumption.

Keywords: Seafood; Heavy metals; Microbial profile; proximate compositions
\end{abstract}

\section{ÉTUDE COMPARATIVE DE LA PROLIFÉRATION MICROBIENNE, PROCHAINE ET HEAVY METAL COMPOSITIONS DE CERTAINS GASTÉROPODES, MOLLUSQUES ET CRUSTACÉS LES FRUITS DE MER}

\section{Oranusi *1, S., Effiong, E. D. et Duru, N. U.}

Département des Sciences Biologiques, Université du Pacte, l'Ota, Nigeria

*Auteur correspondant ; e-mail : solomon.oranusi@covenantuniversity.edu.ng

Résumé

Contexte: les fruits de mer sont connus pour être nutritionnellement riches, cependant, les étendues d'eau d'où ces aliments sont récoltés sont souvent surchargés de déchets provenant des industries, de ruissellement et des ménages. Ainsi, les fruits de mer peuvent héberger des micro-organismes pathogènes et les métaux lourds qui peuvent constituer un grave danger pour la santé des consommateurs. Matériel et méthodes : Dans cette étude, $5 \mathrm{~kg}$ chacun de Littorina littorea, Achatina fulica, Tympanotonos fuscatus, Dorsanum miran, Penaeus notialis Egeria rayonner et ont été étudiés pour les microorganismes, les causes immédiates et qualités de métaux lourds en utilisant des méthodes microbiologiques et chimiques de l'analyse. Résultats: L'amphibien Tympanotonos fuscatus, Littorina littorea et Achatina fulica avaient significativement $(p \leq 0,05)$ les charges microbiennes comparativement à d'autres échantillons. Tous les échantillons avaient significativement $(p \leq 0,05)$ plus élevée de coliformes fécaux par rapport aux spécifications standard. Les isolats microbiens provenant des échantillons des espèces de Bacillus, Klebsiellae, Citrobacter, Providencia, Pseudomonas, Staphylococcus aureus, Escherichia coli et de l'Aspergillus niger, Aspergillus flavus, levures, Alternaria, Absidia, Rhizopus, Mucor et. Antibiogramme des isolats ont révélé de multiples résistances avec $79,55 \%$ et $66,67 \%$ résistance à propriétés antibactériennes et antifongiques, respectivement. Les fruits de mer sont riches en protéines $(8,0 \pm 0,03$ à $46,0 \pm 0,03 \%)$ et de matières grasses $(0,6 \pm 0,01$ à $8,8 \pm$ $1,5 \%)$ mais faible en glucides $(1,18 \pm 0,84$ à $3,81 \pm 0,86 \%)$. Le heavy metal les compositions des fruits de mer ont été généralement faibles, sauf pour le manganèse 6,36 $\pm 0,03 \mathrm{ppm}$ dans Dorsanum miran et nickel 0,81 $\pm 0,50 \mathrm{ppm}$ dans Penaeus notialis. Conclusion : Les charges microbiennes de la mer sont significativement $(p \leq 0,05)$ plus élevée chez les gastropodes et plus de norme acceptable, une protection efficace des plans d'eau pour la culture des aliments et d'une surveillance constante de la mer est nécessaire. Le traitement adéquat et une bonne pratiques de fabrication peuvent réduire la charge microbienne à un niveau acceptable et de prévenir les risques d'origine alimentaire qui pourraient être associés à la consommation de fruits de mer.

Mots-clés: Fruits de mer ; métaux lourds ; profil microbien ; compositions immédiate

Copyright (C2017 AJCEM. This work is licensed under the Creative Commons Attribution 4.0 International License CC-BY 


\section{INTRODUCTION}

Seafood is any fish or shellfish from the sea used for food (1). It includes all fresh or saltwater finfish, mollusks, shellfish, crustaceans, and other forms of edible aquatic animal life (2). Seafood is consumed all over the world (3). It is generally accepted that seafood is important in a healthy, safe, nutritious, and balanced diet. A well-balanced diet that includes a variety of fish and shellfish can contribute to heart health and children's growth and development $(4,5)$. Over one billion people rely on seafood as their primary source of animal protein; it provides the world's prime source of high-quality protein, $14-16 \%$ of the animal protein consumed world-wide (3). Also, seafood is an important source of valuable nutrients, like minerals (e.g., calcium, phosphorus, magnesium, iodine, zinc, copper etc.), vitamins specifically fat soluble vitamins A, D, E, K, fatty acids (e.g., long chain n-3 polyunsaturated fatty acids, EPA-Eicosapentaenoic Acid, DHADocosahexaenoic Acid, and is low in saturated fats $(4,5$, $6,7,8)$. Polyunsaturated $\mathrm{n}-3$ fatty acids in seafood are known to decrease the risks of coronary heart disease and cancer and to improve the response to inflammatory diseases, like psoriasis, and rheumatoid arthritis, increase heart rate variability, decrease the risk of stroke and heart attack, reduce levels of triacylglycerides in serum, reduce blood pressure, reduce insulin resistance and modulate glucose (sugar) metabolism thus help prevent development of diabetes, beneficial effect on patients with attention deficit/hyperactivity disorder (ADHD) and schizophrenia; they are also known to have a beneficial effect on managing depression in adult patients $(9,10$, 11, 12). Seafood products harvested from contaminated waters or which have been improperly preserved after harvesting are known to play an important role in infections, especially by Vibrio spp (13). Consumption of raw or undercooked seafood, particularly shellfish, contaminated with $V$. parahaemolyticus may lead to the development of acute gastroenteritis characterized by diarrhoea, headache, vomiting, nausea, abdominal cramps, and low fever (14). This bacterium is recognized as an important seafood-borne pathogen throughout the world $(15,16)$.

Heavy metals are natural trace components of the aquatic environment, but their levels have increased due to industrial, agricultural and mining activities (17). As a result, aquatic animals are exposed to elevated levels of heavy metals. The levels of metals in upper members of the food web like fish can reach values many times higher than those found in the aquatic environment or in sediments. Thus contamination in the region is an important issue regarding the health of the aquatic animals and, in turn, that of the seafood consumers (17).

Seafood has a natural tendency to concentrate mercury and other heavy metals in their bodies, often in the form of methyl mercury, a highly toxic organic compound of mercury $(18,19)$. Heavy metals pose a great concern as they cause environmental contamination, cannot be degraded further, and their toxic effects can be long lasting, unlike the organic contaminants that decompose into other chemicals with time (20). Heavy metals are known to have toxic effects even at low concentration, and their concentration in biota can be increased through bio-accumulations $(21,22,23)$.

The purpose of this study was to determine and compare the microbial quality, proximate and heavy metal composition of some selected seafood (gastropod mollusks, bivalve mollusk, and crustacean) with a view to contributing microbiological and nutritional information and proffering necessary measures to prevent food borne hazards that could be associated with seafood consumption.

\section{METHODS \\ Collection of samples}

Samples of gastropod mollusks: Littorina littorea (common periwinkle), Achatina fulica (Giant African Land Snail), Tympanotonos fuscatus, Dorsanum miran (sea snail); bivalve mollusk: Egeria radiata (hard clam) and crustacean Penaeus notialis (shrimp), were randomly purchased from ten fishermen and ten seafood vendors in Itu, Akwa Ibom State, Nigeria. Itu is located at $5^{\circ} 10^{\prime} 0^{\prime \prime} 7^{\circ} 59^{\prime} 0^{\prime \prime} \mathrm{E}$ (fig. 1 (24). Two hundred and fifty (250) $\mathrm{g}$ of samples of the seafood from the different sources (fishermen and seafood vendors) were pooled based on types to obtain $5 \mathrm{~kg}$ of each sample type. Samples for further analysis for each of the seafood were from the pool. Samples were washed with distilled water to remove any adhering contamination and were transported in cold chain $4^{\circ} \mathrm{C}$ to the Department of Biological Sciences laboratories of Covenant University for analysis. The samples were identified at the Biology unit of Department of Biological Sciences, Covenant University, Ota, Nigeria.

\section{Sample preparation}

The outer shell of Littorina littorea,Achatina fulica, Tympanotonos fuscatus,, Dorsanum miranand Egeria radiata were washed in running tap water using a nail brush and rinsed in several changes of distilled water. The shells were then disinfected using swabs moistened in $70 \%$ alcohol. After wards, they were de-shelled aseptically. Similarly, the carapace of Penaeus notialis was also removed. Sterile forceps and dissecting kits were employed to remove the edible portions after shells and carapaces were removed for further analyses.

\section{Microbiological analysis}

Twenty-five gram (25g) portion of samples was pulverized in sterile Stomacher lab blender and 


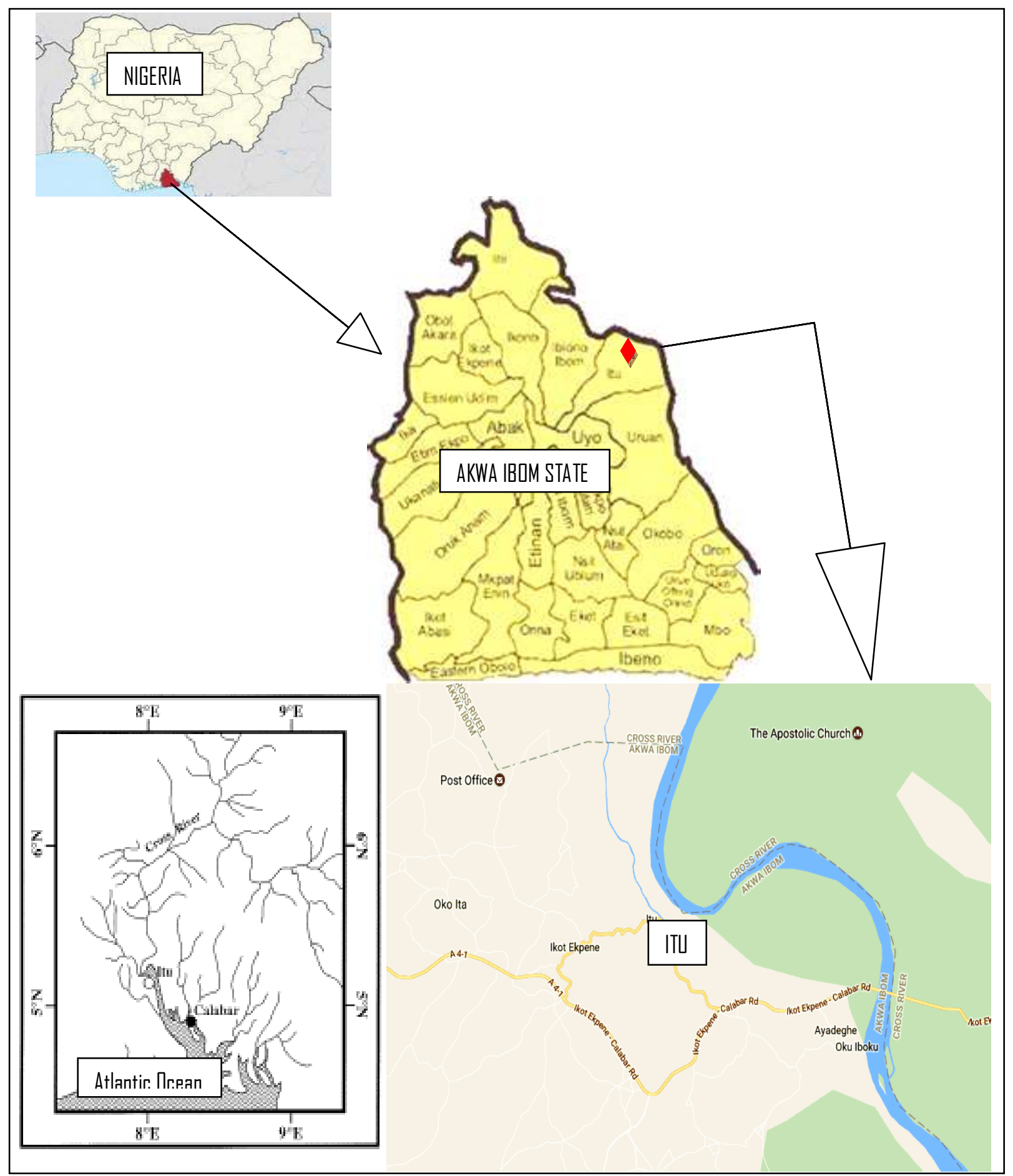

FIGURE 1: MAP OF AKWA IBOM STATE SHOWING STUDY AREA AND ITS LINKS TO THE WATERWAYS. ADAPTED FROM GOOGLE IMAGE, 2017 AND ETIM AND BREY, (1994)(24)

homogenized in $225 \mathrm{~mL}$ distilled water for 1:10 dilution. Further tenfold dilutions of the sample homogenate to $10^{-6}$ were achieved. Aliquot $0.1 \mathrm{~mL}$ of appropriate dilutions were spread plated in triplicate onto Nutrient agar (NA) for total aerobic plate count (TAPC), MacConkey agar (MA) for coliform count and Potato 
dextrose agar (PDA) for the fungal count. One gram (1 g) samples were inoculated into Eosin Methylene blue (EMB) broth with inverted Durham tube in Macartheny bottles and subsequent plating out on Eosin Methylene blue agar after incubation for the coliform test. Cultures on NA, MA, and EMB broth were incubated for 24 to 48 $\mathrm{h}$ at $37^{\circ} \mathrm{C}$. PDA was incubated at $28 \pm 2^{\circ} \mathrm{C}$ laboratory room temperature for 3 to 7 days.

\section{Enumeration and identification of microbial isolates from seafood}

Culture plates were examined at the expiration of incubation period, and colonies were enumerated using Gallenkamp digital colony counter (Gallenkamp, England). Means of total and specific microbial population from the triplicate plates were expressed as colony forming units per $\mathrm{ml}(\mathrm{cfu} / \mathrm{mL})$. Colonial morphology and other cultural characteristics were observed and recorded and pure cultures of microbial isolates were obtained by repeated sub-culturing on appropriate media. Preliminary identification of bacterial isolates was based on cultural, morphological and basic biochemical characteristics; Gram staining, catalase activity, indole, methyl red, Voges Proskaur test, motility, citrate utilization, urease production, oxidase, starch hydrolysis, gelatin liquefaction, coagulase and fermentation of sugars. Further identification of bacterial isolates was based on standard bacteriological procedures (25) and employing the Biomerieux ${ }^{\circledR}$ sa API system. Confirmation for coliform organisms was based on presumptive, confirmatory and completed tests following the description of Speck (26, 27).

Fungal isolates were identified based on cultural and morphological characteristics, pigmentation on media, and microscopic characteristics, sporulation, mycelia arrangement, and sugar assimilation tests and with reference to standard identification key and atlas (28).

\section{Sensitivity test of isolates to commonly used antibiotics and antifungal agents}

Disc diffusion technique as described by Lalitha, (29) and CLSI, (30) was used to carry out the susceptibility testing of the isolates. Three to five colonies of pure isolates were transferred into test tubes containing $5 \mathrm{ml}$ of peptone water and incubated for six hours. The turbidity of the broth culture was adjusted to that of the 0.5 McFarland standards- approximately 1 to $2 \times 10^{8}$ $\mathrm{cfu} / \mathrm{ml}$ (for bacteria). Turbidity for fungal cultures was adjusted to 1 to $5 \times 10^{6}$ cells $/ \mathrm{ml}$. A sterile cotton swab was dipped into the adjusted suspension, rotated several times and pressed firmly on the inside wall of the tube above the fluid level to remove excess inoculum from the swab. The entire dried surface of Müeller-Hinton agar plate (Oxoid) prepared based on manufacturer's instruction, was evenly streak inoculated. Müeller-Hinton agar for fungal sensitivity was, however, supplemented with $2 \%$ glucose $+0.5 \mu \mathrm{g} / \mathrm{ml}$ Methylene Blue Dye. The plates were allowed to stand for 5 minutes to allow for any excess inoculum to diffuse before introducing the discs. The following antimicrobial agents were employed; Cefuroxime $(30 \mu \mathrm{g})$, Ceftriaxone $(30 \mu \mathrm{g})$,

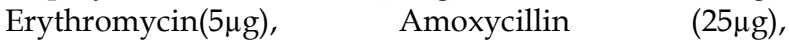
Cotrimetrazole $(25 \mu \mathrm{g})$, Nitrofurantoin $(50 \mu \mathrm{g})$, Gentamycin $(10 \mu \mathrm{g}), \quad$ Nalidixic acid $(15 \mu \mathrm{g})$, Ofloxacin $(5 \mu \mathrm{g})$, Tetracycline $(10 \mu \mathrm{g})$, Streptomycin $(10 \mu \mathrm{g})$, Chloramphenicol $(30 \mu \mathrm{g})$ and Amphotericin B $(20 \mu \mathrm{g})$, Ketoconazole $(15 \mu \mathrm{g}), \quad$ Fluconazole $(25 \mu \mathrm{g})$, Griseofulvin $(10 \mu \mathrm{g})$ and Nystatin(100 unit).The plates were incubated at $37{ }^{\circ} \mathrm{C}$ for $18-24$ hours for bacteria and the fungi culture was kept at room temperature for 5 days after which the zones of inhibition were measured.

\section{Proximate analyses}

The samples were pulverized and the method of the Association of Official Analytical Chemists (AOAC) (31) was adopted for determination of proximate compositions (moisture, protein, lipid, ash, and fibre). The percentage moisture content was measured from 5 g sample oven dried at 100 to $110^{\circ} \mathrm{C}$ to constant weight. The loss in weight multiplied by a hundred was regarded as a measure of moisture. The Nitrogen content in the sample was estimated by the micro Kjeldahl method and crude protein was calculated by multiplying the evaluated nitrogen by a factor of 6.25 (N $\% \times 6.25)$. Total lipid was extracted from the sample with petroleum ether $\left(60\right.$ to $\left.80^{\circ} \mathrm{C}\right)$ in a Soxhlet apparatus for about 6 to 8 hours. The residual solvent was evaporated in a pre-weighed beaker and an increase in the weight of the beaker gave total lipid. Ash was determined from sample heated in a furnace at $550^{\circ} \mathrm{C}$ until white or grayish white ash was obtained. The Weight of the ash was noted directly. Crude fiber was determined by treating the sample with $1.25 \%$ Tetraoxosulphate vi acid $\left(\mathrm{H}_{2} \mathrm{SO}_{4}\right), 1.25 \%$ Sodium hydroxide $(\mathrm{NaOH})$ and then $1 \%$ Nitric acid $\left(\mathrm{HNO}_{3}\right)$, filtered and washed with hot water after each step. The residue obtained was dried in an oven at $130^{\circ} \mathrm{C}$ and ashed at $550^{\circ} \mathrm{C}$ in a furnace. The loss in weight on ignition was expressed as content of crude fiber. The value of total Carbohydrate was determined by the Phenol-Sulfuric Acid Method following the description of Nielsen (32).

\section{Determination of heavy metals}

The heavy metal contents of the samples: lead $(\mathrm{Pb})$, copper $(\mathrm{Cu})$, cadmium $(\mathrm{Cd})$, iron $(\mathrm{Fe})$, zinc $(\mathrm{Zn})$, nickel $(\mathrm{Ni})$, manganese (Mn), and arsenic (As) were determined using the atomic absorption spectrophotomete (G105 UV-VIS, Thermo Fisher Scientific, GeneSys, Madison, USA), as described in the methods of the Association of Official Analytical Chemists (31). 


\section{Statistics}

Results are presented as mean and standard deviations, antibiograms were presented as percentages of susceptibility. One way analysis of variance was employed to compare mean microbial and chemical compositions and correlation analysis and test of significance for the microbial, proximate, heavy metal compositions at $\mathrm{p}=0.05$.

\section{RESULTS}

Table 1 reveals that the gastropod mollusks Tympanotonos fuscatus, Littorina littorea and Achatina fulica had significantly $(\mathrm{p} \leq 0.05)$ higher microbial loads compared to other samples. The table also reveals that all the samples had significantly $(p \leq 0.05)$ higher coliform counts compared to standard specifications.

Table 2 reveals the predominant bacterial and fungal species isolated from each of the seafood samples. It shows that Bacillus, Klebsiella and E. coli were the most predominant bacteria spp, while Aspergillus, yeasts and Mucor were the predominant fungi isolated from the samples.

TABLE 1 MEAN MICROBIAL COUNT (cfu/g) OF THE SEAFOOD SAMPLES

\begin{tabular}{llll}
\hline Sample & TAPC & TCC & TFC \\
\hline Littorina littorea & $4.3 \times 10^{7} \pm 2.06^{\mathrm{b}}$ & $3.9 \times 10^{5} \pm 1.01^{\mathrm{f}}$ & $3.0 \times 10^{6} \pm 1.02^{\mathrm{a}}$ \\
Achatina fulica & $2.0 \times 10^{6} \pm 1.50^{\mathrm{c}}$ & $1.0 \times 10^{6} \pm 2.04^{\mathrm{e}}$ & $1.0 \times 10^{3} \pm 0.02^{\mathrm{d}}$ \\
Tympanotonos fuscatus & $3.0 \times 10^{8} \pm 2.20^{\mathrm{a}}$ & $2.0 \times 10^{5} \pm 1.64^{\mathrm{f}}$ & $2.0 \times 10^{6} \pm 1.84^{\mathrm{a}}$ \\
Dorsanum miran & $1.3 \times 10^{7} \pm 2.64^{\mathrm{b}}$ & $1.5 \times 10^{3} \pm 1.00^{\mathrm{h}}$ & $1.1 \times 10^{5} \pm 0.84^{\mathrm{b}}$ \\
Egeria radiate & $4.0 \times 10^{4} \pm 0.05^{\mathrm{e}}$ & $1.0 \times 10^{4} \pm 0.54 \mathrm{~g}$ & $2.0 \times 10^{4} \pm 0.03^{\mathrm{c}}$ \\
Penaeus notialis & $9.2 \times 10^{5} \pm 1.04^{\mathrm{d}}$ & $2.5 \times 10^{3} \pm 0.06^{\mathrm{h}}$ & $1.4 \times 10^{5} \pm 0.34^{\mathrm{b}}$ \\
\hline
\end{tabular}

KEY: TAPC= Total Aerobic plate count, TCC $=$ Total coliform count, TFC=Total fungal count. Super script abcdefgh= counts with different superscript for the same count (within the same column) are significantly different

TABLE 2 PREDOMINANT BACTERIAL AND FUNGAL SPECIES ISOLATED FROM SEAFOOD

\begin{tabular}{|c|c|c|}
\hline Sample & Bacteria spp isolated & Fungi spp isolated \\
\hline Littorina littorea & Escherichia coli; Bacillus spp; Acinetobacter spp & Aspergillus niger, Aspergillus flavus, yeast \\
\hline Achatina fulica & $\begin{array}{l}\text { Klebsiella spp; Staphylococcus; Citrobacter spp; } \\
\text { Bacillus spp }\end{array}$ & Aspergillus niger, mucor, streptomyces spp \\
\hline Tympanotonos fuscatus & Escherichia coli; Pseudomonas spp; Bacillus spp & Yeast, mucor, Aspergillusspp, Aspergillusniger \\
\hline Dorsanum miran & $\begin{array}{l}\text { Bacillus sp;Staphylococcus sp; Escherichia } \\
\text { coli;Aeromonas spp }\end{array}$ & cerevisiae; Mucor sp; \\
\hline Egeria radiate & Klebsiella sp; Bacillus sp, Citrobacter spp & Mucor sp Alternaria, Absidia, Rhizopus \\
\hline Penaeus notialis & $\begin{array}{l}\text { Bacillus sp; Pseudomonas spp, Aeromonas spp, } \\
\text { Klebsiella spp }\end{array}$ & $\begin{array}{l}\text { Penicillium spp, Aspergillus } \\
\text { Saccharomyces cerevisiae }\end{array}$ \\
\hline
\end{tabular}

Table 3 and 4 reveals that the bacterial isolates were multi-resistant to the antimicrobial agents. Pseudomonas gave $90.91 \%$ resistance and Klebsiella showed $81.82 \%$ resistance. These organisms were $100 \%$ resistant to Cotrimoxazole, Tetracycline, and Chloramphenicol and all the bacterial isolates were $79.55 \%$ resistant to all the antibacterial agents and $20.45 \%$ were sensitive. Table 4

The proximate composition of the seafood samples is shown in Table 5. It explains that seafood is rich in protein, lipid, and ash and have high moisture, total solid and organic matter contents. The proximate analysis shows that the crude protein contents ranged from 8.0 to $46.0 \%$, total lipid and carbohydrate contents ranged from 0.6 to $8.8 \%$ and 1.18 to $3.81 \%$ respectively. shows that all the fungal isolates were $60 \%$ and above resistant to the antifungal agents, except for Alternaria spp. Species of Penicillium and Absidia were 100\% resistant to the antifungal agents tested. All the fungal isolates were $66.67 \%$ resistant to all the antifungal agents and $33.33 \%$ sensitive.

Penaeus notialis (crustacean) and bivalve mollusk (Egeria radiata) has significantly $(\mathrm{p} \leq 0.05)$ higher protein content than the gastropods except for Dorsanum miran. The lipid contents of the samples were not significantly different, except however, for Dorsanum miran which has significantly $(p \leq 0.05)$ higher lipid content and Penaeus notialis with significantly $(\mathrm{p} \leq 0.05)$ lower lipid content compared to all other samples 
TABLE 3 PERCENTAGE (\%) SUSCEPTIBILITY OF BACTERIAL ISOLATES TO COMMONLY USED ANTIBACTERIAL AGENTS

\begin{tabular}{|c|c|c|c|c|c|c|c|c|c|c|c|c|c|c|c|c|c|}
\hline IORGANISM & OFL & GEN & COT & AMX & TET & AUG & STR & CHL & ERY & CTR & NAL & CRX & CAZ & NIT & CLX & $\% \mathrm{~S}$ & $\% R$ \\
\hline Bacillus sp. & $S$ & $S$ & $\mathbf{R}$ & $\mathbf{R}$ & $\mathbf{R}$ & $\mathbf{R}$ & $\mathbf{R}$ & $\mathbf{R}$ & $\mathbf{R}$ & - & - & - & - & $S$ & $\mathbf{R}$ & 27.27 & 72.73 \\
\hline $\begin{array}{l}\text { Klebsiella } \\
s p .\end{array}$ & $\mathbf{R}$ & $S$ & $\mathbf{R}$ & - & $\mathbf{R}$ & - & $\mathbf{R}$ & $\mathbf{R}$ & - & $\mathbf{R}$ & $\mathrm{S}$ & $\mathbf{R}$ & $\mathbf{R}$ & $\mathbf{R}$ & - & 18.18 & 81.82 \\
\hline Staph. sp. & $S$ & $S$ & $\mathbf{R}$ & $\mathbf{R}$ & $\mathbf{R}$ & $\mathbf{R}$ & $S$ & $\mathbf{R}$ & $\mathbf{R}$ & - & - & - & - & $\mathbf{R}$ & $\mathbf{R}$ & 27.27 & 72.73 \\
\hline Pseudo. sp. & S & $\mathbf{R}$ & $\mathbf{R}$ & - & $\mathbf{R}$ & - & $\mathbf{R}$ & $\mathbf{R}$ & - & $\mathbf{R}$ & $\mathbf{R}$ & $\mathbf{R}$ & $\mathbf{R}$ & $\mathbf{R}$ & - & 9.09 & 90.91 \\
\hline$\% S$ & 75.0 & 75.0 & 0.0 & 0.0 & 0.0 & 0.0 & 25.0 & 0.0 & 0.0 & 0.0 & 50.0 & 0.0 & 0.0 & 25.0 & 0.0 & 20.45 & \\
\hline$\% \mathbf{R}$ & 25.0 & 25.0 & 100 & 100 & 100 & 100 & 75.0 & 100 & 100 & 100 & 50.0 & 100 & 100 & 75.0 & 100 & & \\
\hline
\end{tabular}

Key: OFL=Oflaxacin, GEN=Gentamycin, COT=Cotrimoxazole, AMX=Amoxicillin, TET=Tetracycline, AUG=Augmentin, $\mathrm{STR}=$ Streptomycin, $\mathrm{CHL}=$ Chloramphenicol, ERY=Erythromycin, $\mathrm{CTR}=$ Ceftriaxone, $\mathrm{NAL}=$ Nalidixic acid, CRX=Cefuroxime, CAZ=Ceftrazidime, NIT=Nitrofurantoin, CLX=Cloxacillin, $R=$ Resistant, $S=$ Sensitive, \% S= \%Susceptible, \% R= \% Resistant, Not applicable

TABLE 4 PERCENTAGE (\%) SUSCEPTIBILITY OF FUNGAL ISOLATES TO COMMONLY USED ANTIFUNGAL AGENTS

\begin{tabular}{|c|c|c|c|c|c|c|c|}
\hline IGANISM & AMC.B & KTZ & FLZ & GRV & NYT & $\% \mathrm{~S}$ & $\% \mathbf{R}$ \\
\hline Aspergillus niger & $S$ & $\mathrm{~S}$ & $\mathbf{R}$ & $\mathbf{R}$ & $\mathbf{R}$ & 40 & 60 \\
\hline Aspergillus flavus & $\mathbf{R}$ & $S$ & $\mathbf{R}$ & $\mathrm{S}$ & $\mathbf{R}$ & 40 & 60 \\
\hline Yeast. & $S$ & $\mathrm{~S}$ & $\mathbf{R}$ & $\mathbf{R}$ & $\mathbf{R}$ & 40 & 60 \\
\hline Mucor spp & $S$ & $\mathbf{R}$ & $\mathbf{R}$ & $S$ & $\mathbf{R}$ & 40 & 60 \\
\hline Streptomyces spp & $\mathrm{S}$ & $\mathbf{R}$ & $S$ & $\mathbf{R}$ & $\mathbf{R}$ & 40 & 60 \\
\hline Penicillium spp & $\mathbf{R}$ & $\mathbf{R}$ & $\mathbf{R}$ & $\mathbf{R}$ & $\mathbf{R}$ & 00 & 100 \\
\hline Alternaria $s p p$ & $\mathbf{R}$ & $\mathrm{S}$ & $\mathrm{S}$ & $\mathrm{S}$ & $\mathbf{R}$ & 60 & 40 \\
\hline Absidia $s p p$ & $\mathbf{R}$ & $\mathbf{R}$ & $\mathbf{R}$ & $\mathbf{R}$ & $\mathbf{R}$ & 00 & 100 \\
\hline Rhizopus $s p p$ & $\mathbf{R}$ & $\mathrm{S}$ & $\mathbf{R}$ & $\mathbf{R}$ & $\mathrm{S}$ & 40 & 60 \\
\hline$\% \mathrm{~S}$ & 44.44 & 55.56 & 22.22 & 33.33 & 11.11 & 33.33 & \\
\hline$\% \mathbf{R}$ & 55.56 & 44.44 & 77.78 & 66.67 & 88.89 & & \\
\hline
\end{tabular}

KEY: AMC=Amphotericin B, KTZ=Ketoconazole, FLZ=Fluconazole, GRV=Griseofulvin NYT=Nystatin

TABLE 5 PERCENTAGE (\%) PROXIMATE COMPOSITION OF SEAFOOD

\begin{tabular}{|c|c|c|c|c|c|c|c|c|}
\hline SAMPLE & Moisture & Protein & Lipid & Ash & Fibre & $\begin{array}{l}\text { Total } \\
\text { carbohy } \\
\text { Drate }\end{array}$ & $\begin{array}{l}\text { Total solid } \\
\text { (dry } \\
\text { matter) }\end{array}$ & $\begin{array}{l}\text { Organic } \\
\text { matter }\end{array}$ \\
\hline $\begin{array}{l}\text { Littorina } \\
\text { littorea }\end{array}$ & $51.80 \pm 2.04^{a}$ & $8.0 \pm 0.03 \mathrm{a}$ & $4.18 \pm 0.05^{a}$ & $19.80 \pm 0.22^{a}$ & $8.48 \pm 2.05^{a}$ & $1.94 \pm 1.05^{\mathrm{a}}$ & $48.20 \pm 0.05^{a}$ & $80.20 \pm 2.34^{a}$ \\
\hline $\begin{array}{l}\text { Achatina } \\
\text { fulica }\end{array}$ & $55.10 \pm 3.05^{a}$ & $32.0 \pm 0.01^{b}$ & $4.77 \pm 0.23^{a}$ & $4.21 \pm 0.68 \mathrm{~b}$ & $7.08 \pm 1.01^{\mathrm{a}}$ & $2.52 \pm 1.04^{a}$ & $44.90 \pm 1.44^{\mathrm{a}}$ & $95.79 \pm 1.02^{b}$ \\
\hline $\begin{array}{l}\text { Tympanotonos } \\
\text { fuscatus }\end{array}$ & $74.80 \pm 2.02^{b}$ & $27.0 \pm 0.02^{b}$ & $5.20 \pm 0.08^{a}$ & $4.16 \pm 0.60^{b}$ & $2.88 \pm 0.05^{b}$ & $2.67 \pm 1.03^{a}$ & $25.20 \pm 0.98^{b}$ & $95.84 \pm 1.00^{\mathrm{b}}$ \\
\hline $\begin{array}{l}\text { Dorsanum } \\
\text { miran }\end{array}$ & $68.80 \pm 1.22^{\mathrm{ab}}$ & $43.0 \pm 0.05^{c}$ & $8.80 \pm 1.00 \mathrm{c}$ & $12.71 \pm 1.05^{c}$ & $4.00 \pm 0.05 \mathrm{~b}$ & $1.32 \pm 0.23 c$ & $31.20 \pm 0.08 c$ & $87.29 \pm 1.66^{a}$ \\
\hline $\begin{array}{l}\text { Penaeus } \\
\text { notialis }\end{array}$ & $74.50 \pm 1.01^{b}$ & $46.0 \pm 0.02^{c}$ & $0.60 \pm 0.01^{b}$ & $5.36 \pm 0.54^{b}$ & $3.83 \pm 1.01^{b}$ & $3.81 \pm 0.86^{b}$ & $25.50 \pm 0.06^{b}$ & $94.64 \pm 2.02^{b}$ \\
\hline
\end{tabular}

Super script abc= values with different superscript for the same parameter (within the same column) are significantly different 
Table 6 reveals the heavy metal composition of the seafood samples. It shows that lead and Arsenic were not detected in the samples except for trace amount in some samples. Dorsanum miran had significantly $(\mathrm{p} \leq 0.05)$ higher levels of $\mathrm{Mn}, \mathrm{Zn}$ and $\mathrm{Cu}$ compared to other samples except for $\mathrm{Cu}$ in Littorina littorea. The correlation among microbial load (0.331), proximate composition (0.223) and heavy metal composition (0.192) was weak.

TABLE 6 HEAVY METAL COMPOSITIONS (PPM) OF SEAFOOD

\begin{tabular}{|c|c|c|c|c|c|c|c|c|}
\hline SAMPLE & Mn & $\mathrm{Fe}$ & $\mathrm{Zn}$ & $\mathrm{Ni}$ & $\mathrm{Cd}$ & $\mathrm{Cu}$ & $\mathrm{Pb}$ & As \\
\hline Littorina littorea & $0.722 \pm 0.01^{a}$ & $5.28 \pm 0.05^{b}$ & $17.2 \pm 0.05^{a}$ & $0.16 \pm 0.00^{a}$ & $0.12 \pm 0.02^{a}$ & $7.56 \pm 0.31^{\mathrm{c}}$ & trace & Nil \\
\hline Achatina fulica & Trace & $2.32 \pm 0.02 \mathrm{a}$ & $2.6 \pm 0.01^{b}$ & $0.12 \pm 0.10^{a}$ & $0.14 \pm 0.01 \mathrm{a}$ & $2.83 \pm 0.04 \mathrm{a}$ & Nil & Nil \\
\hline $\begin{array}{l}\text { Tympanotonos } \\
\text { fuscatus }\end{array}$ & $2.190 \pm 0.04^{a}$ & $1.98 \pm 0.01 \mathrm{a}$ & $3.5 \pm 0.02 \mathrm{~b}$ & $0.15 \pm 0.01 \mathrm{a}$ & $0.12 \pm 0.00 \mathrm{a}$ & $1.50 \pm 0.01^{\mathrm{a}}$ & Nil & Trace \\
\hline Dorsanum miran & $6.36 \pm 0.03 \mathrm{~b}$ & $2.90 \pm 0.05 \mathrm{a}$ & $23.1 \pm 0.02 \mathrm{a}$ & $0.11 \pm 0.00^{a}$ & $0.16 \pm 0.00 \mathrm{a}$ & $4.55 \pm 0.20^{b}$ & Nil & Trace \\
\hline Egeria radiate & $1.02 \pm 0.01^{\mathrm{a}}$ & $2.14 \pm 0.02^{\mathrm{a}}$ & $5.3 \pm 0.01^{b}$ & $0.23 \pm 0.01^{\mathrm{a}}$ & $0.15 \pm 0.01 \mathrm{a}$ & $1.64 \pm 0.02^{\mathrm{a}}$ & trace & Nil \\
\hline Penaeus notialis & Trace & $1.81 \pm 0.04$ a & $5.5 \pm 0.01 \mathrm{~b}$ & $0.81 \pm 0.50$ a & $0.13 \pm 0.00 \mathrm{a}$ & $2.71 \pm 0.03$ a & trace & Nil \\
\hline 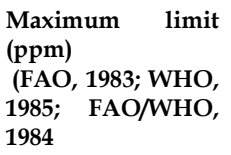 & 50 & - & $30-50$ & 80 & $0.3-1.0$ & $20-30$ & 1.5 & - \\
\hline
\end{tabular}

Key: $\mathrm{Mn}=$ Manganese, $\mathrm{Fe}=$ Iron, $\mathrm{Zn}=\mathrm{Zinc}, \mathrm{Ni}=\mathrm{Nickel}, \mathrm{Cd}=$ Cadmium, $\mathrm{Cu}=\mathrm{Copper}, \mathrm{Pb}=\mathrm{Lead}, \mathrm{As}=$ Arsenic,$-=\mathrm{Not}$ provided Super script $a b c=$ values with different superscript for same parameter (within same column) are significantly different

\section{DISCUSSION}

The total microbial count obtained in this study shows that the microbial quality of the seafood samples was poor compared to the specified standard limit. According to the International Commission on Microbiological Specifications for Food (ICMSF) (33), a total aerobic plate count (TAPC) of not more than $5 \times 10^{5}$ $\mathrm{cfu} / \mathrm{g}$ is recommended for fresh bivalve mollusks and $10^{7} \mathrm{cfu} / \mathrm{g}$ for raw crustaceans. It means that Littorina littorea,Tympanotonos fuscatus, Achatina fulica and Dorsanum miran had total aerobic plate counts significantly $(\mathrm{p} \leq 0.05)$ higher than the recommended microbial limits for fresh mollusks. Similarly, maximum total coliform count recommended by ICMSF33 is 11 $\mathrm{cfu} / \mathrm{g}$ for raw crustaceans of good quality products and $500 \mathrm{cfu} / \mathrm{g}$ for marginally acceptable quality products. Maximum coliform level recommended for fresh bivalve mollusk is $16 \mathrm{cfu} / \mathrm{g}$. Table 1 reveals that all the samples had coliform counts significantly $(\mathrm{p} \leq 0.05)$ well above the recommended microbial limits. The higher microbial counts in the gastropod mollusks compared to bivalves could be associated with the univalve anatomy that tends to trap and incubate more materials that sieve into the mollusks.

Salmonella and vibrio species were not isolated from examined seafood thus this report is not in tandem to the report of Adebayo-Tayo et al (34), who reported the isolation in a high number of salmonella and vibrio species from seafood. Coliforms (E. coli, Klebsiella,
Citrobacter) and Staphylococcus aureus were, isolated in significantly high counts and from a large number of the seafood samples examined. This is in conformity with the reports of Nwiyi and Okonkwo (35), Zaky and Ibrahim (36); Although Nwiyi and Okonkwo (35) isolated high number of salmonella which is at variance with this report. Coliforms are indicators of faecal contamination, and this is corroborated by isolation of faecal E. coli from the samples analyzed, their presence in these samples is of public health significance. The presence of $S$. aureus calls for concerns, as this organism has been implicated in foodborne diseases ${ }^{37}$ and is associated with various human diseases (38). S. aureus is a normal human flora and can easily contaminate processed food product, control of its presence in raw foods will help minimize the presence in finished products. Contamination by these microorganisms of water bodies from where the seafood were harvested could be from human activities such as bathing, disposal of faecal matters, sewage discharge by municipal authorities, runoff, unhygienic handling and improper packaging/transportation and storage by the fishermen and seafood vendors (39, 40, 41). Fish and other free-swimming marine animals do not usually carry those organisms generally considered to be typical of the mammalian microflora, including Escherichia coli, the 'faecal coliforms', and enterococci. The presence of human enteric organisms on marine food products is clear evidence of contamination from a terrigenous 
source (36). Dabadé et al (42) evaluated the bacterial concentration and diversity in fresh tropical shrimps (Penaeus notialis) and the surrounding brackish waters and sediment and observed that total mesophilic aerobic counts in shrimp samples were significantly higher than in water or sediment samples. In contrast, bacterial diversity was higher in sediment or water than in shrimps. They concluded that the bacterial community of tropical brackish water shrimps cannot be predicted from the microbiota of their aquatic environment. The results of this work corroborate some reports on the bacteriology of seafood $(43,44,45)$.

Fungal species are spore bearers and common environmental contaminants of food and food products. The isolation of these organisms in seafood is in tandem with the reports of $(36,46,47,48,49)$. These fungi are observed as pathogens or opportunistic pathogens in fresh and salt water fishes and have also been implicated in veterinary and human diseases $(27,50$, 51). The presence of these fungi in seafood could be associated with contamination from the water environment, the fishermen and vendors, and instrument of fishing $(52,53,54,55)$.

The antibiogram revealed that most of the microbial isolates were multi-resistant to the common antimicrobial agents; this report is in tandem with the observations of Zaky and Ibrahim, 36 that screened bacterial and fungal biota associated with Oreochromis niloticus, it, however, differs from the report of Shimaa et al (56) who reported high sensitivity of bacterial isolates from ponds cultured Indian shrimps. That most organisms in this study are multi-resistant to the common antimicrobial agents, could be explained that theseorganisms may have been subjected to several harsh environmental conditions and exposed to sublethal doses of antimicrobial substances, causing them to adapt and mutate into resistant strains. Inappropriate use of antimicrobials, lack of health care personnel with continual health education on antimicrobials and poor quality drugs have also been reported as a major cause of antimicrobial agents resistance specifically in developing countries (57, 58).Several mechanical, epidemiological and genetic factors may lead to the development of drug resistance $(57,59,60,61)$. The occurrence of drug resistance genes in microbial isolates will result in microorganisms that are multi-resistant to virtually all antimicrobial agent. This poses a serious public health concern because should such a multi-drug resistant organism cause infection, empirical treatment will be difficult $(57,58,62)$.

The nutritional composition of the samples revealed high protein and lipid content for some of the seafood samples, this compares favourably with similar works reported by other researchers $(8,34,63,64,65,66)$. The proximate values, however, differ significantly with the reports of some commercially important seafood presented by Mohammad and Yusuf ${ }^{67}$. Mean levels of heavy metals in the sea food samples were generally found to be below the acceptable limits of heavy metal pollution of fishes and shell fishes $(68,69,70,71)$. A level of $0.81 \mathrm{ppm}$ was reported for nickel in Penaeus notialis, Nwabueze (72) reported a higher level of nickel in Egeria radiate harvested from creeks in Delta state, Nigeria. The mineral levels reported for shellfishes by Davies and Jamabo (73) is higher than the level presented in this work. Manganese was detected in the sea snail sample at $6.36 \mathrm{ppm}$. This level is significantly $\mathrm{p} \leq 0.05$ higher than the adequate intake (AI) levels stipulated for infants $(0.003 \mathrm{mg} /$ day), for adult male $(2.3 \mathrm{mk} /$ day) and $2.6 \mathrm{mg} /$ day in lactation. The level reported is however within the range stipulated for tolerable upper intake level (UL) $2 \mathrm{mg} /$ day to $11 \mathrm{mg} /$ day for infants and adults respectively. Manganese is both nutritionally essential and potentially toxic; it plays an important role in a number of physiologic processes as a constituent of multiple enzymes and an activator of other enzymes (74). There is little risk of excessive exposure to manganese through ingestion of fish or shellfish emanating from contaminated waters unless the manganese levels in the fish are extremely high and/or the fish are eaten as subsistence. The inhalation of air contaminated with particulate matter containing manganese is the primary source of excess manganese exposure for the general population (74, 75, 76). Manganese toxicity can result in early symptoms such as irritability, aggressiveness, and hallucinations this will be followed by a permanent neurological disorder known as manganism with symptoms that include tremors, difficulty walking, facial muscle spasms, adverse cognitive effects, including difficulty with concentration and memory problems (74, 75, 76). Although the levels of heavy metals presented in this work are low, some researchers $(22,23,77,78)$ however, observed that heavy metals have relatively high density and are toxic or poisonous even at low concentrations. In view of this, there is a need for constant monitoring of the levels of heavy metals to forestall any significant rise in their levels resulting in ecological and health concerns such as biochemical variations, mutations, deformities and sometimes death in the organism, bioaccumulation in the food chain and toxicity to man $(79,80,81)$.

\section{Conclusion}

The present study revealed that samples of the selected seafood from Itu, Akwa Ibom state Nigeria contain an unacceptable level of microorganisms, the presence of organisms such as feacal Escherichia coli, other coliforms, and Staphylococcus species implies a poor sanitary condition of the water bodies from where the samples were harvested. The gastropod mollusks had 
significantly higher microbial loads than the bivalve mollusk and crustacean. The isolated organisms prove to be multi-resistant to commonly used antibacterial and antifungal agents, this presents serious public health concerns. The seafood is nutritionally rich and with low heavy metal concentrations. This study did not establish a significant difference in the proximate and heavy metal compositions of the gastropod mollusks, bivalve mollusk, and crustacean. Effective policing of water bodies for seafood cultivation by all concerned is necessary, public enlightenment campaign on the need to keep the water bodies free of pollutants and the health benefits of seafood consumption is advocated.

\section{Conflict of interest}

Authors declare no conflict of interest and have approved the submission of this article to this journal

\section{Significance Statement}

This study discovers that gastropod mollusks are often more contaminated than bivalve mollusk and

\section{REFERENCES}

1. Random House Kernerman Webster's College Dictionary, 2010. K Dictionaries Ltd. Random House. Retrieved May 24, 2017 from: http://www.thefreedictionary.com/seafood

2. Okonko, I. O., Adejoye, O. D., Ogun, A. A., Ogunjobi, A. A., Nkang, A. O. and Adebayo-Tayo, B. C., 2009. Hazards analysis critical control points (HACCP) and microbiology qualities of sea-foods as affected by handler's hygiene in Ibadan and Lagos, Nigeria.Afr. J. Food Sci.,3(2): 035-050.

3. Tidwell, J. H. and Allan, G. L., 2002. Fish as food: aquaculture's contribution ecological and economic impacts and contributions of fish farming and capture fisheries. World Aquaculture,33 (3): 44-48.

4. Seafood Health Facts, 2016. Making smart choices balancing the benefits and risks of seafood consumption resources for healthcare providers and consumers. Delaware Sea Grant. http://www.seafoodhealthfacts.org/seafoodnutrition/healthcare-professionals/seafood-nutritionoverview. Accessed May 24, 2017.

5. Ab-Lah, R., Smith, J., Savins, D., Dowell, A., Bucher, D. and Benkendorff, K., 2017. Investigation of nutritional properties of three species of marine turban snails for human consumption. Food Sci. Nut., 5(1): 14-30. doi: 10.1002/fsn3.360.

6. Kris-Etherton, P. M., Harris, W. S. and Appel, L. J., 2002. Fish consumption, fish oil, omega-3 fatty acids, and cardiovascular disease, Circulation, 106(21): 2747-2757.

7. Nesheim, M. C. and Yaktine, A. L., 2007. Seafood choices: Balancing benefits and risks analysis of the crustacean from the same water environment. The isolated organisms were multi-resistant with $79.55 \%$ resistance to all the antibacterial agents and above $60 \%$ resistance to the antifungal agents. This work also observed that there was no significant difference in the heavy metal compositions of the gastropod mollusks, bivalve mollusk, and crustacean from the same environment. This study will help the researcher to uncover the critical area of aquaculture and seafood processing and preservation

\section{Authors Contributions}

Author Oranusi, S. designed, supervised and wrote the manuscript

Authors Effiong, E.D. and Duru, N. U. Performed the laboratory analysis and wrote the draft

\section{Acknowledgement}

Authors appreciate Covenant University management for the platform created for this research.

balancing of benefits and risks of seafood consumption, National Academies Press, Washington, DC, USA.

8. Padidela, S. and Thummala, R. R., 2015. Proximate, amino acid, fatty acid and mineral analysis of bivalve Parreysia cylindrica from Waddepally and Kaleshwaram lake. World J. Pharm. Pharmaceut. Sci., 4: 1388-1401.

9. Gil, A., 2002. Polyunsaturated fatty acids and inflammatory disease, Biomed.Chromatography, 56(8): 388-396.

10. Roynette, C. E., Calder, P. C., Dupertuis, Y. M. and Pichard, C., 2004. n-3 polyunsaturated fatty acids and colon cancer prevention, Clin. Nut., 23(2): 139-151.

11. Harper, C. R. and Jacobson, T. A., 2005. Usefulness of omega- 3 fatty acids and the prevention of coronary heart disease, Am. J. Cardiol., 96(11): 1521-1529, 2005.

12. FAO/WHO, 2011. Report of the Joint FAO/WHO Expert Consultation on the Risks and Benefits of Fish Consumption: Rome, 25-29 January 2010. FAO Fisheries and Aquaculture Report No. 978.

13. Baffone, W., Pianetti, A., Bruscolini, F., Barbieri, D. and Citterio, B., 2000. Occurrence and expression of virulence related properties of Vibrio species isolated from widely consumed seafood products. Int. J. Food Microbiol.,54: 9-18.

14. Popovic, N. T., Skukan, A. B., Dzidara, P., Coz-Rakovac, R., Strunjak-Perovic, I., Kozacinski, L., Jadan, M. and Brlek-Gorski, D., 2010. Microbiological quality of marketed fresh and frozen seafood caught off the Adriatic coast of Croatia.Vet. Med.55(5): 233-241.

15. Farmer, J. J., Janda, M. and Birkhead, K., 2003. Vibrio. In: Murray, P. R., Baron, E. J., Jorgensen, J. H., Pfaller, M. A. 
\& Yolken, R. H. (editors.): Manual of Clinical Microbiology. $8^{\text {th }}$ edition. ASM Press, Washington, pp 706-718.

16. Su, Y. C. and Liu, C., 2007. Vibrio parahaemolyticus: A concern of seafood safety. Food Microbiol., 24: 549-558.

17. Stancheva, M., Makedonski, L. and Petrova, E., 2013. Determination of heavy metals $(\mathrm{Pb}, \mathrm{Cd}, \mathrm{As}$ and $\mathrm{Hg})$ in black sea grey mullet Mugil Cephalus. Bulg.J. Agric. Sci., 19 (1): 30-34.

18. FDA, 2012. Mercury Levels in Commercial Fish and Shellfish (1990-2012) U.S. Food and Drug Administration. Accessed 24 May 2017.

19. Wikipedia, 2017. Mercury in fish. https://en.wikipedia.org/wiki/Mercury_in_fish\#cite_not e- FDA-1. Accessed 24 May 2017

20. Akporhonor, E. E., Iwegbue, C. M. A., Egwaikikhide, P. A. and Emua, S. A., 2007. J. Chem. Soc. Nig., 32(1): 221 226.

21. Ganagaiya, P. I., Tabudrawa, T. R., Suth, R. and S. Satheesrraran, S., 2001. Heavy metal contamination of Lami coastal Environment, Fiji. The South. Pacific J. Nat. Sci., 19: 24 - 29 .

22. Lenntech, R. (2004) Lenntech water treatment and air purification. Rotterdamseweg, Netherlands. Available online: http//www.excelwater.com/thp/filters/WaterPurification.htm. Accessed on 25/05/ 2017

23. Mansouri, N., Khorasani, N., Monavari, S. M., Karbasi, A. and Panahandeh, M., 2013.Non-carcinogenic risk estimation of $\mathrm{Cr}, \mathrm{Cd}, \mathrm{Pb}$ in human to fish consumption from Anzali Wetland. World J. Fish and Marine Sci., 5 (6): 603-610. DOI: 10.5829/idosi.wjfms.2013.05.06.74212.

24. Etim, L., and Brey, T., 1994. Growth, productivity and significance of the bivalve Egeria radiata (Donacidae) in Cross River, Nigeria. Arch. Fisheries and Marine Res.42: 63-75.

25. Jolt J.G., Krieg, N. R., Sneath, P. H. A., Stanley, J. T. and Williams, S. T., 1994. Bergey's Manual of Systematic Bacteriology, 9th ed., Williams \& Wilkins Co. Baltimore, Maryland, 786.

26. Speck, M. L. 1976. Compendium of Methods for Microbiological Examination of Foods. 4th ed., American Public Health Association, Washington D.C., USA. pp 277-328.

27. Oranusi, S., Nwachukwu, C., Adekeye, B.T., Dahunsi, O. S. and Adeyemi, A. O., 2013. Microbial profile, antibacterial and antioxidant activities of some imported spices in Nigeria. Eur. J. Exp. Biol. 3(6):193-202.
28. Tsuneo, W., 2010. Pictorial atlas of soil and seed fungi: Morphologies of cultural fungi and Key to Species. Third edition CRC press 2010.

29. Lalitha, M.K., 2004. Manual on antimicrobial susceptibility testing (Under the auspices of Indian Association of Medical Microbiologists)

30. CLSI (Clinical and Laboratory Standards Institute, 2012. Performance standards for antimicrobial disk susceptibility tests; approved standard-eleventh edition. CLSI document M02-A11. Wayne, PA: Clinical and Laboratory Standards Institute; 2012.

31. AOAC (Association of Official Analytical Chemists), 2008. Official Methods of Analysis (18 ${ }^{\text {th }}$ Ed.), AOAC, Arlington, USA.

32. Nielsen, S. S., 2010. Phenol-Sulfuric Acid Method for Total Carbohydrates, In Food Analysis Laboratory Manual, Springer Food Science Texts Series pp 47-53. DOI 10.1007/978-1-4419-1463-7_6. ISBN 978-1-4419-14637. http://rd.springer.com/chapter/ 10.1007\%2F978-1-4419$\underline{1463-7 \_6}$

33. ICMSF (International Commission on Microbiological Specifications for Food), 1986. Microorganisms in Food 2. Sampling for microbiological analysis: Principles and specific applications.2 $2^{\text {nd }}$ edition. Blackwell Scientific Publications, UK. Retrieved May 25, 2017 from: http://www.icmsf.org/pdf/icmsf2.pdf

34. Adebayo-Tayo, B. C., Onilude, A. A. and Etuk, F. I., 2011. Studies on microbiological, proximate, mineral and heavy metal composition of freshwater snails from Niger Delta creek in Nigeria.A.U. J. T., 14(4): 290-298.

35. Nwiyi, P. and Okonkwo, C., 2013. Pathogenic microorganisms isolated from periwinkles in creeks south-south of Nigeria. Online J. Animal and Feed Res. 3(4):186-188. $\quad$ http://www.science-line.com/index/; http://www.ojafr.ir.

36. Zaky, M. and Ibrahim, M., 2017. Screening of bacterial and fungal biota associated with Oreochromis niloticus in lake Manzala and its impact on human health. Health9: 697-714. doi:10.4236/ health.2017.94050.

37. Balaban, N. and Rasooly, A., 2000. Staphylococcal enterotoxins. Int. J. Food Microbiol.,61:1-10.

38. Ayepola, O. O., Olasupo, N. A., Egwari, L. O., Becker, K. and Schaumburg, F., 2015. Molecular characterization and antimicrobial susceptibility of Staphylococcus aureus isolates from clinical infection and asymptomatic carriers in southwest Nigeria. PLoS ONE 10(9):e0137531 DOI:10.1371/journal.pone.0137531 Available from: https://www.researchgate.net/publication/281622049Mo lecular_Characterization_and_Antimicrobial_Suscepti bility_of_Staphylococcus_aureus_ Isolates_from_Clinical_Infection_and_Asymptomatic Carriers_in_Southwest_Nigeria Accessed May 24, 2017. 
39. Antony, M. M., Jeyasekaran, G., Shakila, R. J. and Shanmugam, S. A., 2002. Microbiological quality of raw shrimps processed in seafood processing plants of Tuticorin, Tamil Nadu, India. Asian Fisheries Sci. 15 (1): 33-41.

40. Dalzochio, T. and Gehlen, G., 2016. Confounding factors in biomonitoring using fish. Ecotoxicol. Environ. Contam. 11 (1): 53-61. doi: 10.5132/eec.2016.01.08.

41. VIeira, C.E.D., Costa, P. G., Lunardelli, B., Oliveira, L.F., Cabrera, L. C., Risso, W. E., Primel, E. G., Meletti, P. C., Fillmann, G. and Martinez, C. B. R., 2016. Multiple biomarker responses in Prochilodus lineatus subjected to short-term in situ exposure to streams from agricultural areas in Southern Brazil. Sci Total Environ. 542:44-56. 2015.10.071 http://dx.doi.org/10.1016/j.scitotenv.

42. Dabadé, D. S., Wolkers-Rooijackers, V, Azokpota, P., Hounhouigan, V, Zwietering, M. H., Nout, M. J. R. and Den- Besten, H. M.W., 2016.Bacterial concentration and diversity in fresh tropical shrimps (Penaeus notialis) and the surrounding brackish waters and sediment. Int. J. Food Microbiol., 218: 96-104. http://doi.org/10.1016/j.ijfoodmicro.2015.11.013.

43. Ekanem, E. O. and Adegoke, G. O., 1995. Bacteriological study of West Africanclam (Egeria

radiata Lamarch) and their overlying waters. Food Microbiol., 12: 381-385.

44. Hatha, A. A. M., Christi, K. C. Singh, R. and Kumar, S., 2005. Bacteriology of the fresh water bivalve clam Batissa violacea (Kai) sold in the Suva market. The South. Pacific J. Nat. Sci.23: 48-50.

45. Adjei-Boateng, D., Amisah, S. and Quagrainie, K. K. 2009.Bacteriological contamination of the fresh water clam Galatea paradoxa) from the Volta estuary, Ghana. Afr. J. Microbiol. Res., 3(7): 396-399.

46. Refai, M.K., Laila, A. M., Amany, K. M. and El-S. Shimaa, M. A., 2010. The assessment of mycotic settlement of freshwater fishes in Egypt. J. Am. Sci. 6: 595-602.

47. Junaid, S. A., Olauboin, F. and Olabode, A. O., 2010. Mycotic contamination of stock fish sold in Jos, Nigeria. J. Yeast and Fungal Res. 1: 136-141.

48. Iqbal, Z., Sheikh, U. and Mughal, R., 2012. Fungal infections in some economically important freshwater fishes. Pak. Vet. J., 32: 422-426.

49. Iqbal, Z. and Saleemi, S., 2013. Isolation of pathogenic fungi from a freshwater commercial fish, Catla catla (Hamliton). Sci. Int. (Lahore) 25: 851- 855.

50. Salem-Bekhe, M.M., Abd-Al-Azeem, M.W. and Hashim, E.S.Y., 2011. Mycological aspect of smoked fish at retail outlet at the delta province of Egypt. J. Appl. Env. Biol. Sci. 1: 26-31.

51. Oranusi, S., Obioha, T. U. and Adekeye, B.T., 2014. Investigation on the microbial profile of frozen foods: Fish and Meat. Int. J. Adv. Res. Biol. Sci., 1(2): 71-78.
52. Geldreich, E.E. and Clarke, N. A., 1966. Bacterial pollution indicators in the intestinal tract of freshwater fish. Appl. Env. Microbiol., 14: 429-437.

53. Lund, B.M., 2000. Freezing, In Lund B.M., Baird Parker and Gould T.C. (eds.), The Microbiological Safety and Quality of Food. Springer. ISBN 978-0-8342-1323-4.

54. Adams, M.R. and Moss, M.O., 2008. Food Microbiology $3^{\text {rd }}$ edition. The Royal Society of Chemistry, Cambridge. ISBN 978-0-85404-284-5.

55. Loir, Y.,. Baron, F. and Gautier, M., 2003. Staphylococcus aureus and food poisoning. Genetic and molecular res. 2(1), 63-76.

56. Shimaa, A.H. E., Riad, H. K., Talaat, T. S., El-Tanekhy, M. and Hany, M. R. A., 2015. Occurrence, characterization and antibiotic resistance patterns of bacterial communities encountered in mass kills of pond cultured Indian prawn Fenneropenaeus indicus at Damietta governorate, Egypt. Int. J. Fisheries and Aquatic Studies 2(4): 271-276.

57. Yah, S. C., Eghafona, N. O., Oranusi, S. and Abouo, A. M., 2007. Widespread plasmids resistance transfers genes among Proteus species in diabetic wounds of patients in the Ahmadu Bello University Teaching Hospital (ABUTH) Zaria. Afr. J. Biotechnol. 6(15): 17571762.

58. Jakee, J. E., Moussa, E. I., Mohamed, K. F. and Mohamed, G., 2009. Using molecular techniques for characterization of Escherichia coli isolated from water sources in Egypt. Global Veterinaria, 3 (5): 354-362.

59. Bennett, P. M., 2008. Plasmid encoded antibiotic resistance: Acquisition and transfer of antibiotic resistance genes in bacteria. Br. J. Pharmacol., 153 (1): 347-357.

60. Canton, R., 2009. Antibiotic resistance genes from the environment: A perspective through newly identified antibiotic resistance mechanisms in clinical setting. European Society of Clin. Microbiol. Infec. Diseases, 15 (1): $20-25$

61. Hung, D. T. and Kaufman, B. B., 2010. The fast track to multi-drug resistance. Int. Molecular Cell Biology, 37 (3): 297-298

62. Gubala, A. J. and Proll, D. F., 2006. Molecular-Beacon Multiplex Real-Time PCR Assay for Detection of Vibrio cholerae. Appl. Env. Microbiol.,72 (9): 6424-6428.

63. Job, B. E. and Ekanem, A. P., 2010. Nutritional status of two periwinkle species from a tropical creek in Nigeria. Afr. J. Environ. Pollut. Health 8 (1): 41-44.

64. Bello, B. K., 2013. Effect of processing methods on the proximate and mineral composition of prawn (Penaeus notialis).J. Global Biosciences 2(2): 42-46. 
65. Ehigiator, F. A. R. and Akise, O. G., 2016. Proximate, amino acid and mineral composition of wild and cultured fresh water clam Egeria radiata. NJAFE. 12(2):103-108

66. Bernard, E. and Bolatito, A. Y., 2016. Comparative study on the nutritional composition of the pink shrimp (Penaeus notialis) and tiger shrimp (Penaeus monodon) from Lagos lagoon, Southwest Nigeria. Cogent Food and $\quad$ Agriculture, $\quad 2$ 2: 1201891. http://dx.doi.org/10.1080/23311932. 2016.1201891.

67. Mohammad, S. H. and Yusuf, M. S., 2016. Proximate evaluation of some economical seafood as a human diet and as an alternative prospective valuable of fish meal. J. Fisheries and Aquatic Sci. 11 (1): 12-27. DOI: 10.3923/jfas.2016.12.27.

68. FAO (Food and Agriculture Organization), 1983.Compilation of legal limits for hazardous substances in fish and fishery products. FAO Fish Circ., 464: 5-100.

69. WHO (World Health Organization), 1985. Guidelines for Drinking Water Quality, Vol. 1, Recommendation WHO, Geneva, pp: 130.

70. FAO/WHO, 2001. Food Standards Programme Codex Alimentarius Commission Report of the 33rd Session of The Codex Committee On Food Additives And Contaminants. Twenty-fourth session geneva, Switzerland. pp 181-183. Retrieved May 17, 2017 from: http://ftp.fao.org/codex/Reports/

Alinorm01/A10112ae.pdf

71. FAO/WHO, 1984. List of maximum levels recommended for contaminants by the Joint FAO/WHO Codex Alimentarius Commission. Second Series. CAC/FAL, Rome, 3: 1-8.

72. Nwabueze, A. A., 2010. Heavy metals concentrations in tissues of Egeria radiate from creeks in Burutu south local government area of Delta state, Nigeria. J. Env. Issues and Agric. in Dev. Countries2(2 \& 3): 67-74.

73. Davies, I. C. and Jamabo, N. A., 2016. Determination of mineral contents of edible parts of shellfishes from
Okpoka creeks in Rivers state, Nigeria. Int. J. Fisheries and Aquaculture Res. 2 (2):10-18.

74. Higdon, J., Drake, V. J. and Aschner, M., 2017. Manganese. Linus Pauling Institute Micronutrient Information Center, Oregon State University, http://lpi.oregonstate.edu/mic/minerals/manganese

775. Francis, A. A. and Forsyth, C., 1995. Toxicity summary for manganese. Oak Ridge Reservation Environmental Restoration Program. Available at hydratechnm.org/.../toxicity_summar_for_manganese

76. FNB (Food and Nutrition Board, Institute of Medicine), 2001. Manganese. Dietary reference intakes for vitamin A, vitamin $\mathrm{K}$, boron, chromium, copper, iodine, iron, manganese, molybdenum, nickel, silicon, vanadium, and zinc. Washington, D.C.: National Academy Press; 2001:394-419.

77. Nolan, K., 2003. Copper Toxicity syndrome. J. Orthomol. Psychiatry 12(4): 270 - 282.

78. Zbaar, S. A. and Marbut, S. M., 2004. Heavy metal contamination of drinking water in the city of Baiji. IASJ.http://iasj.net/iasj?func=fulltext\&aId $=60743$

79. Udoidiong O.M. andAkpan, P.M., 1991. Toxicity of cadmium, lead and lindane to Egeria radiata Lamarck (Lamelibranchia, Donacidae). Revue d'Hydrobiologie Tropicale 24 (2): 111-117. ISSN 0240-8783. http://horizon.documentation.ird.fr/exldoc/pleins_textes/cahiers/hydrob-trop/35850.pdf

80. More, T. G., Rajput, R. A. and Bela, N. N., 2003: Impact of heavy metals on DNA content in the whole body of freshwater bivalve, Lamelleiden marginalis. Env. Sci. Pollut. Res., 22: 605-616.

81. Thakur, J. and Mhatre, M., 2015. Bioaccumulation of heavy metals in Tilapia Mossambicus fish from industrially polluted Patalganga river, India. Int. J. Adv. Res. 3(2): 486-490. 